\title{
Analisis Isi Berita Lokal Dalam Program Acara "WARTA 21" di TVRI Bangka Belitung
}

\author{
Siti Sarifah \\ Sekolah Tinggi Multi Media Yogyakarta \\ e-mail ; siti_sarifah78@yahoo.com
}

\begin{abstract}
Abstrack
This study an analyzes the contents of the local news program Warta 21 in TVRI Bangka Belitung. TVRI Bangka Belitung has only been established for three years and is the youngest TVRI among other TVRIs, that it has limited human resources, equipment, as well as funding. This study provides input for LPP TVRI Bangka Belitung about the contents of local news Warta 21. This study implements quantitative content analysis method using a sample of 146 local news items in the Warta 21 news program. The results of the research are (1) From the news material, the majority contents of the news are about social, Disaster, Transportation, Culture, Weather, Scientific, and Traffic Accident in small amounts. (2) Seen from the sources of the news, the news content majority are about the government and the least is the news coming from the community. (3) From the value of the news, the majority content are news with timeliness value and news that has the least value are about weather, conflict, dissaster, as well as sports news, with editorial policy consideration, then the coverage is carried out based on the nwes that has wider impact (4) From the type of news coverage, the majority content comes from the planned coverage, where the least comes from advanced coverage.
\end{abstract}

Keywords: News Category, Daily News, TVRI, Content Analysis

\begin{abstract}
Abstrak
Penelitian ini berisi tentang analisis isi berita lokal acara "Warta 21" di TVRI Bangka Belitung. TVRI Bangka Belitung, baru berdiri tiga tahun dan merupakan TVRI termuda memiliki keterbatasan SDM, alat dan pendanaan. Penelitian ini memberikan masukan bagi LPP TVRI Bangka Belitung tentang isi materi Berita Lokal "Warta 21". Penelitian ini menggunakan metode analisis isi kuantitatif dengan menggunakan sampel sebanyak 146 item berita lokal dalam acara "Warta 21". Hasil penelitiannya adalah (1) Dari materi berita, mayoritas adalah berita sosial dan berita Berita Bencana, Transportasi, Budaya, Cuaca, Ilmiah, dan Kecelakaan dalam jumlah yang sedikit. (2) Dilihat dari narasumber, mayoritas dari pemerintah dan yang paling sedikit dari masyarakat. (3) Dilihat dari nilai berita, mayoritas adalah berita dengan nilai timeliness dan yang paling sedikit yang bernilai berita Weater, conflict, Dissaster dan sport, dengan pertimbangan kebijakan redaksi, liputan yang dilakukan berdasarkan yang berdampak lebih luas (4) Dilihat dari jenis liputan berita, mayoritas berasal dari liputan terencana dan yang paling sedikit dari liputan lanjutan
\end{abstract}

Kata Kunci: Kategori Berita, TVRI, Berita Harian, Analisis Isi 


\section{Pendahuluan}

Televisi sebagai media massa elektronik memiliki peranan cukup penting dalam kehidupan masyarakat terutama sebagai alat penyebar informasi, disamping sebagai media pendidikan dan hiburan. Keunggulan media televisi dibandingkan dengan media lain, televisi memiliki siaran yang dipancarkan menjangkau seluruh lapisan masyarakat dan memiliki daya tarik khusus sebagai media "pandang dengar" (audio visual) sebagai sumber informasi mampu mengejar nilai aktualitas, karena dengan cepat dan mudah menyampaikan pesan kepada khalayak tanpa hambatan ruang dan waktu. Keunggulan televisi dibanding media cetak tersebut benarbenar harus dimanfaatkan oleh penyelenggara TVRI, agar pesan yang disampaikan dapat mempengaruhi pola pikir masyarakat kearah perilaku positif.

Pada awal perkembangannya keberadaan TVRI waktu itu sangat dibutuhkan oleh masyarakat karena satu satunya media massa elektronik yang menyiarkan berita. Pada era reformasi sekarang ini keberadaan TVRI tidak seperti dulu lagi, sebab dihadapkan pada suasana kompetitif dengan banyaknya media cetak maupun media elektronik swasta yang juga menyiarkan informasi dan hiburan.

Program acara berita merupakan salah satu paket acara dalam sebuah lembaga penyiaran. Informasi melalui siaran berita membawa pengaruh yang sangat besar, terutama bagi perkembangan pembangunan dewasa ini. Berita di televisi merupakan salah satu acara yang sangat penting. Berita menjadi semacam ciri khas sebuah stasiun untuk menunjukkan keunggulannya dan menjadi ujung tombak untuk mengangkat image sebuah stasiun.

Junaedi (2013:3) menyatakan “ Berita telah menjadi bagian yang tidak dapat dilepaskan dari kehidupan kita. Setiap harinya banyak berita yang bermunculan dalam kehidupan kita . Radio maupun televisi menyiarkan berita yang bukan hanya berasal dari kejadian yang sudah terjadi tetapi juga berita yang sedang berlangsung (live), perkembangan teknologi internet juga mempercepat penyebaran berita. Berita yang dihadirkan dari beragam media massa ini juga terdiri dari berbagai jenis berita yang disajikan, mulai dari berita politik, ekonomi, sosial, budaya, hukum, olah raga dan lain sebagainya" Oleh karenanya dalam penyajian informasi melalui acara siaran berita diperlukan metode yang baru dan menarik sehingga mampu memikat minat para penonton. Salah satu program acara yang diminati adalah program acara berita harian (Bulletin Berita).

Berita harian ini menarik masyarakat dan harus melihat mana yang bernilai berita dan mana yang tidak dari semua peristiwa yang terjadi di sekitarnya. Berita harian ini sangat menarik karena cara mengungkapkannya yang dilakukan secara cepat dan aktual. Seorang reporter dituntut untuk dapat meliput secara cepat, aktual dan akurat serta memiliki kepekaan untuk dapat mencari berita yang bernilai berita yang tinggi.

Salah satu televisi pemerintah di Indonesia adalah LPP TVRI Bangka Belitung, yang baru berdiri sekitar tiga tahun dan merupakan TVRI termuda yang berdiri. Sebagai stasiun televisi yang belum lama berdiri memiliki banyak keterbatasan dibandingkan dengan TVRI yang ada di Indonesia, keterbatasan itu meliputi seperti SDM, Alat dan pendanaan. Namun TVRI Babel tidak kalah dalam siaran out putnya siarannya, baik dari sisi kualitas maupun kuantitas.

Sebagai Lembaga Penyiaran Publik TVRI Babel berusaha menyajikan siaran berita yang bervariatif, salah satunya program acara "Warta 21" yang disiarkan setiap hari Senin sampai dengan Minggu setiap pukul 17.00 WIB.

Warta 21 disiarkan setiap hari yang berisi tentang Berita Lokal (tidak terbatas) yang berisi berita faktual dari Bangka Belitung, Berita Lintas Andalas (berita-berita di Sumatera), berita seputar lintas nasional, segmen olah raga dan informasi cuaca, namun dalam penelitian ini, peneliti hanya menyoroti mengenai berita lokal dalam acara "Warta 21".

Peneliti mengambil obyek ini karena TVRI Bangka Belitung merupakan salah satu 
TVRI seluruh Indonesia yang belum lama berdiri karena baru tiga tahun dan sudah menerapkan pola kerja one man show. Berita terdiri dari berbagai jenis, menurut JB Wahyudi (1996) jenis berita diantaranya :

1. Berita Terkini (Bulletin Berita).

2. Berita Berkala (News Magazine). Berita "Warta 21" termasuk salah satu Bulletin Berita, Bulletin Berita menurut Masduki (2001) adalah gabungan beberapa berita pendek yang disajikan dalam satu blok waktu. Kecenderungan isi materi berita pada program acara "Warta 21" didominasi oleh berita kehidupan masyarakat yang mencapai 90 persen. Siaran "Warta 21" terdiri dari berita Lintas Andalas, Lintas Nusantara,Berita Olah Raga dan Berita Lokal Bangka Belitung, dalam hal ini peneliti hanya menyoroti berita lokalnya saja, karena yang murni dari reporter TVRI Bangka Belitung dan memenuhi syarat untuk penelitian dengan menggunakan metode analisis isi.

Penelitian ini bertujuan untuk mengetahui isi materi Berita Lokal pada program acara "Warta 21" di LPP TVRI Bangka Belitung. Ciriciri berita adalah aktual, disusun sesuai kaidah jurnalistik, berita yang disampaikan berimbang atau cover both side dan disiarkan secepat mungkin. Dengan adanya berita, kebutuhan masyarakat akan informasi akan terpenuhi.

Menurut Muda (2003) berikut ada beberapa pengertian tentang berita dari berbagai sumber yang dapat disimpulkan bahwa berita adalah suatu fakta atau ide atau opini aktual yang menarik dan akurat serta dianggap penting bagi sejumlah besar pembaca, pendengar maupun penonton.

Materi sebagai bahan berita berasal dari berbagai sumber masalah. Materi berita berdasarkan soal (masalah) yang dicakupnya menurut Assegaff (1982), diantaranya :
a. Berita Politik (Berita politik dan kenegaraan)
b. Berita Ekonomi
c. Berita Kejahatan

d. Berita Kecelakaan/kebakaran

e. Berita Olah Raga

f. Berita Militer

g. Berita Ilmiah

h. Berita Pendidikan

i. Berita Agama

j. Berita Pengadilan

k. Berita "Dunia Wanita"

1. Berita "Manusia dan Peristiwa

Menurut Muda (2003) beberapa nilai berita yang akan menjadi acuan dalam menjalani proses jurnalistik dan kejadian yang dianggap punya nilai berita atau layak disiarkan adalah yang mengandung satu atau beberapa hal sebagai berikut :

meliness Timeliness berarti waktu yang tepat, artinya memilih berita yang akan disajikan harus sesuai dengan waktu yang dibutuhkan oleh masyarakat pemirsa atau pembaca.

\section{Proximity}

Proximity artinya kedekatan. Kedekatan di sini maknanya sangat bervariasi, yakni dapat berarti dekat dilihat dari segi lokasi, pertalian ras, profesi, kepercayaan, kebudayaan maupun kepentingan yang terkait lainnya.

\section{Prominence}

Artinya adalah orang yang terkemuka. Semakin seseorang itu terkenal maka akan semakin menjadi bahan berita yang menarik pula.

\section{Consequence}

Pertimbangan keempat adalah konsekuensi atau akibat, pengertiannya yaitu, segala tindakan atau kebijakan, peraturan, perundangan dan lain-lain yang dapat berakibat merugikan atau menyenangkan orang banyak, merupakan bahan berita yang menarik.

Conflict

Conflict (konflik) memiliki nilai berita 
yang sangat tinggi karena konflik adalah bagian dalam kehidupan.

Development

Development (pembangunan) merupakan materi berita yang cukup menarik apabila reporter yang bersangkutan mampu mengulasnya dengan baik.

Dissaster \& Crimes

Dissaster (bencana) dan crimes (kriminal) adalah dua peristiwa berita yang pasti akan mendapatkan tempat bagi pemirsa atau penonton.

Weather

Weather (cuaca) di Indonesia atau di negara-negara yang berada di sepanjang garis katulistiwa memang tidak banyak terganggu.

a.

Sport

Berita olah raga sudah lama memiliki daya tarik. Negara yang maju biasanya akan maju pula prestasi olah raganya. Human Interest

Kisah-kisah yang dapat membangkitkan emosi manusia seperti lucu, sedih, dramatis, aneh dan ironis merupakan peristiwa menarik dari segi human interest.

Menurut Harahap dalam Badjuri (2010: 34) ada empat jenis liputan dalam berita televisi, yaitu :

a. Liputan berita momentum (moment news).

Berita yang tak teragendakan, berita yang berasal dari peristiwa yang tiba-tiba kecelakaan, gempa, banjir, kebakaran, kriminalitas).

b. Liputan Berita Terencana (Event News)

Berita terencana atau teragendakan dibuat berdasarkan peristiwa yang disengaja, direncanakan, atau diagendakan (pers, unjuk rasa, kegiatan olah raga, hari-hari besar)

c. Liputan Berita Fenomena

Berasal dari peristiwa yang sudah menggejala atau menjadi fenomena (kemiskinan, pengemis, tradisi dan lain-lain)

d. Liputan Berita Lanjutan (follow-up news)

Ide berita jenis ini berasal dari berita yang telah ditayangkan, merupakan lanjutan atau follow up dari berita yang telah ditayangkan sebelumnya (misal berita tentang perkelahian pelajar yang menyebabkan mahasiswa tewas, kemudian beberapa saat setelah itu ada berita meliput pemakaman.

\section{Metode Penelitian}

Dalam penelitian ini, peneliti menggunakan metode analisis isi deskriptif kuantitatif. Analisis isi menurut Narendra (2008) merupakan sebuah alat riset yang digunakan untuk menyimpulkan kata atau konsep yang tampak di dalam teks atau rangkaian teks.

Peneliti menggunakan materi berita "Warta 21" selama periode bulan September 2017 sebagai obyek penelitian dan populasi penelitian. jadi lokasi penelitian ada di TVRI Bangka Belitung, sedangkan waktu pelaksanaan yaitu tanggal 23 s.d. 29 September 2017.

Populasi merupakan keseluruhan obyek atau subyek yang berada pada suatu wilayah dan memenuhi syarat-syarat tertentu berkaitan dengan masalah penelitian atau keseluruhan unit atau individu dalam ruang lingkup yang diteliti (Martono, 2010: 66). Dalam penelitian ini populasinya adalah materi berita lokal dalam acara "Warta 21" LPP TVRI Bangka Belitung selama 24 hari mulai tanggal 1 sampai 24 Oktober 2017 yang keseluruhan beritanya berjumlah 229 aitem berita.

Salah satu metode yang digunakan untuk menentukan jumlah sampel adalah menggunakan rumus Slovin (sevilla et.al., 1960:182) sebagai berikut :

$$
\mathrm{N}=\frac{\mathrm{N}}{1+\mathrm{N} \text { e2 }}
$$

Dimana : $\mathrm{n}=$ jumlah sampel $\mathrm{N}=$ jumlah populasi

$\mathrm{E}=$ batas toleransi kesalahan 
(error toleransi)

Menurut Arikunto (1977) Cara pengambilan sampel dari populasi dengan memberikan kesempataan yang sama bagi anggota populasi untuk terpilih menjadi anggota sampel (Sampel Random/Sampel Acak. Cara mengambil dari sampling Random ini ada tiga cara : undian, ordinal dan table bilangan random. Untuk efisien waktu, tenaga dan pikiran peneliti memakai cara undian. Keabsahan dalam penelitian ini menggunakan Teknik Trianggulasi yang Uji reliabilitas perlu dilakukan untuk melihat tingkat konsistensi pengukuran data. Guna melihat apakah data yang dipakai dalam analisis isi dapat memenuhi harapan, maka dipakai metode intercoder reliabiliti menggunakan formula Holsti.

Materi Berita Lokal dalam acara "Warta 21" yang menjadi objek penelitian ini adalah edisi bulan September 2017 dengan jumlah populasi sebanyak 229 aitem berita, kemudian diambil sampel dari 229, yaitu setelah dimasukkan rumus Slovin yang dijadikan sampel sebanyak 146 aitem berita yang diundi secara acak dan terpilih aitem berita untuk tanggal 1,2,3,7,9,11,12,14,15,19,21,22,2 3,24 September sebagai sampel penelitian.

Teknik analisis data yang digunakan adalah teknik analisis deskriptif kuantitatif dengan menggunakan formula Hosti untuk mengukur reliabilitas antar coder. Formula Hosti ini pertama kali diperkenalkan oleh R. Holsti. Reliabilitas ini ditunjukkan dalam presentase persetujuan berapa besar presentase persamaan antar coder ketika menilai suatu isis (Eriyanto 2011:290). Berikut formula Hosti :

$$
\text { Reliabilitas Antar-Coder }=\frac{2 \mathrm{M}}{\mathrm{N} 1+\mathrm{N} 2}
$$

Keterangan

$\mathrm{M}=$ Jumlah Coding yang sama

$$
\mathrm{N} 1=\quad \text { Jumlah }
$$

coding yang dibuat oleh coder 1 N2 $\quad$ Jumlah coding yang dibuat oleh coder 2

\section{Hasil dan Pembahasan}

Dalam penelitian ini, yang bertindak sebagai coder 1 adalah peneliti sendiri, coder 1 adalah Siti Sarifah, coder 2 adalah Retno Kusdiati (Dosen dan Praktisi dalam Program Studi Manajemen Produksi Pemberitaan dan telah lama bekerja di TVRI Yogyakarta). Dalam analisis ini menggunakan formula Holsti untuk mengukur reliabilitas antar coder, dengan formula Holsti :

Untuk menghitung reliabilitas antar coder digunakan rumus

$$
\begin{aligned}
\mathrm{CR} & =\frac{2 \mathrm{M}}{\mathrm{N} 1+\mathrm{N} 2} \\
& =\frac{2(122)}{146+146} \\
& =0,8
\end{aligned}
$$

Hasil perhitungan dengan menggunakan rumus reliabilitas koder formla Holsti, menunjukkan bahwa kesepakatan hubungan antar pengkoding (coder) untuk materi berita sebesar $80 \%$. Maka

Tabel 1

Tabel Uji Reliabilitas

\begin{tabular}{|c|c|c|c|c|c|c|c|c|}
\hline & \multicolumn{2}{|c|}{$\begin{array}{c}\text { Berdasarkan } \\
\text { Materi Berita } \\
\text { N=146 }\end{array}$} & \multicolumn{2}{c|}{$\begin{array}{c}\text { Berdasarkan } \\
\text { Narasumber } \\
\text { N=146 }\end{array}$} & \multicolumn{2}{c|}{$\begin{array}{c}\text { Berdasarkan } \\
\text { Nilai Berita } \\
\text { N=146 }\end{array}$} & \multicolumn{2}{c|}{$\begin{array}{c}\text { Berdasarkan } \\
\text { Jenis Liputan } \\
\text { N=146 }\end{array}$} \\
\cline { 2 - 9 } & Setuju & $\begin{array}{c}\text { Tidak } \\
\text { setuju }\end{array}$ & Setuju & $\begin{array}{c}\text { Tidak } \\
\text { Setuju }\end{array}$ & Setuju & $\begin{array}{c}\text { Tidak } \\
\text { Setuju }\end{array}$ & Setuju & $\begin{array}{c}\text { Tidak } \\
\text { Setuju }\end{array}$ \\
\hline $\begin{array}{c}\text { Coder } \\
1\end{array}$ & 122 & 24 & 140 & 6 & 134 & 12 & 126 & 20 \\
\hline $\begin{array}{c}\text { Coder } \\
2\end{array}$ & 122 & 24 & 140 & 6 & 134 & 12 & 126 & 20 \\
\hline
\end{tabular}


berdasarkan penafsiran yang dikemukakan $\mathrm{J}$ Holsti untuk materi berita memiliki korelasi yang cukup.

Uji Reliabilitas Berdasarkan Narasumber, sampel yang dijadikan coding sheet diambil secara acak dalam penelitian ini maka akan dijelaskan mengenai tema berita tayang tersebut berdasarkan hasil koding sebagai berikut.

Untuk menghitung reliabilitas antar coder digunakan rumus

$$
\begin{aligned}
\mathrm{CR} & =\frac{2 \mathrm{M}}{\mathrm{N} 1+\mathrm{N} 2} \\
& =\frac{2(140)}{146+146} \\
& =0,9
\end{aligned}
$$

Hasil perhitungan dengan menggunakan rumus reliabilitas koder formla Holsti, menunjukkan bahwa kesepakatan hubungan antar pengkoding (coder) untuk materi berita sebesar $90 \%$. Maka berdasarkan penafsiran yang dikemukakan $\mathrm{J}$ Holsti untuk materi berita memiliki korelasi yang cukup. Uji Reliabilitas Berdasarkan Nilai Berita yang diperoleh, sampel yang dijadikan coding sheet diambil secara acak dalam penelitian ini maka akan dijelaskan mengenai tema berita tayang tersebut berdasarkan hasil koding sebagai berikut.

Untuk menghitung reliabilitas antar coder digunakan rumus

$$
\begin{aligned}
\mathrm{CR} & =\frac{2 \mathrm{M}}{\mathrm{N} 1+\mathrm{N} 2} \\
& =\frac{2(134)}{146+146} \\
& =0,9
\end{aligned}
$$

Hasil perhitungan dengan menggunakan rumus reliabilitas koder formla Holsti, menunjukkan bahwa kesepakatan hubungan antar pengkoding (coder) untuk materi berita sebesar $90 \%$. Maka berdasarkan penafsiran yang dikemukakan J Holsti untuk materi berita memiliki korelasi yang cukup.

Uji Reliabilitas Berdasarkan Jenis Liputan, sampel yang dijadikan coding sheet diambil secara acak dalam penelitian ini maka akan dijelaskan mengenai tema berita tayang tersebut berdasarkan hasil koding sebagai berikut.

Untuk menghitung reliabilitas antar coder digunakan rumus

$$
\begin{aligned}
\mathrm{CR} & =\frac{2 \mathrm{M}}{\mathrm{N} 1+\mathrm{N} 2} \\
& =\frac{2(126)}{146+146} \\
& =0,8
\end{aligned}
$$

Hasil perhitungan dengan menggunakan rumus reliabilitas koder formla Holsti, menunjukkan bahwa kesepakatan hubungan antar pengkoding (coder) untuk materi berita sebesar $80 \%$. Maka berdasarkan penafsiran yang dikemukakan $\mathrm{J}$ Holsti untuk materi berita memiliki korelasi yang cukup. Dalam penelitian ini pengkoding diwajibkan menganalisis unit-unit penelitian berdasarkan kategori terlampir sebagai berikut ini. Sedangkan untuk Kontruk kategori berita lokal "Warta 21" berdasarkan sumber berita, narasumber, nilai berita, jenis liputannya, yaitu

Tabel 2

Berdasarkan Materi Berita

\begin{tabular}{|c|l|c|c|}
\hline No & \multicolumn{1}{|c|}{ Hari Beritaan } & Frekuensi & Persentase \\
\hline 1 & Berita Politik & 9 & $6 \%$ \\
\hline 2 & Berita Ekonomi & 22 & $15 \%$ \\
\hline 3 & Berita Kejahatan & 26 & $17 \%$ \\
\hline 4 & Berita Kecelakaan/Kebakaran & 1 & $1 \%$ \\
\hline 5 & Berita Olah Raga & 2 & $1 \%$ \\
\hline 6 & Berita Militer & - & - \\
\hline 7 & Berita Ilmiah & 1 & $1 \%$ \\
\hline 8 & Berita Pendidikan & 19 & $13 \%$ \\
\hline 9 & Berita Agama & 1 & $1 \%$ \\
\hline 10 & Berita Pengadilan & 2 & $2 \%$ \\
\hline 11 & Berita "Dunia Wanita" & 5 & $3 \%$ \\
\hline 12 & Berita "Manusia dan Peristiwa" & 32 & $21 \%$ \\
\hline 13 & Sosial & 1 & $1 \%$ \\
\hline 14 & Budaya & 1 & $1 \%$ \\
\hline 15 & Cuaca & 1 & $1 \%$ \\
\hline 16 & Transportasi & 146 & $2 \%$ \\
\hline 17 & Sosial Politik & & \\
\hline 18 & Bencana & Jumlah & $1 \%$ \\
\hline
\end{tabular}


Penyajian berita lokal "Warta 21" di TVRI Bangka Belitung dari dilihat dari materi beritanya mayoritas berita dari berita sosial kemudian kemudian berita kejahatan dan berita yang materi beritanya sedikit ada Berita Bencana, Transportasi, Budaya, Cuaca, Ilmiah, dan Kecelakaan, hal ini disebabkan karena materi berita yang diambil oleh reporter di TVRI Bangka Belitung dengan pertimbangan bahwa materinya tergantung dari perkembangan isu-isu pada hari, minggu dan bulan tersebut, jadi berita social menempati urutan tertinggi karena isu yang berkembang pada bulan tersebut kebanyakan materi sosial.

Kategori pengukuran berita lokal "Warta 21" yang penulis sajikan dibawah ini adalah berita harian yang meliputi kategori: berdasarkan narasumber adalah sebagai berikut.

\section{Tabel 3}

Berdasarkan Narasumber

\begin{tabular}{|c|c|c|c|}
\hline No & Narasumber & Frekuensi & Persentase \\
\hline 1 & $\begin{array}{ll}\text { Publik Figur } \\
\text { - } & \text { Gubernur } \\
- & \text { Bupati } \\
- & \text { Kapolda } \\
- & \text { Wakil Gubernur }\end{array}$ & 35 & $23 \%$ \\
\hline 2 & Masyarakat & 45 & $30 \%$ \\
\hline 3 & $\begin{array}{ll}\text { Aparat Pemerintah } \\
- & \text { Kepala Lapas } \\
\text { - } & \text { GM Angkasa Pura } \\
- & \text { BMKG } \\
\text { - } & \text { Dinas Peternakan } \\
\text { - } & \text { Rumah sakit } \\
\text { - } & \text { Polisi, Polres } \\
- & \text { Dinas Pertanian } \\
- & \text { Kepala Basarnas } \\
& \text { Dll }\end{array}$ & 70 & $47 \%$ \\
\hline & & 146 & 100 \\
\hline
\end{tabular}

Penyajian berita lokal "Warta 21" di TVRI Bangka Belitung dari dilihat dari narasumber dikategorikan mayoritas narasumber dari pemerintah dan yang paling sedikit dari narasumber dari masyarakat, disebabkan karena persoalan yang dihadapi oleh masyarakat Bangka Belitung banyak melibatkan aparat pemerintah, dalam menentukan narasumber berita diawali dari pertemuan redaksi yang membahas tentang topic of the day, bisa juga disebabkan karena Bangka Belitung minim mencari seorang pengamat dari sebuah permasalahan yang dihadapi. Kategori pengukuran berita lokal "Warta 21" yang penulis sajikan dibawah ini adalah berita $\mathrm{h}$ arian yang meliputi kategori berita berdasarkan nilai berita.

\section{Tabel 4}

\section{Berdasarkan Nilai Berita}

\begin{tabular}{|c|l|c|c|}
\hline No & Hari Beritaan & Frekuensi & Persentase \\
\hline 1 & Consequence & 20 & $14 \%$ \\
\hline 2 & Prominence & 18 & $13 \%$ \\
\hline 3 & Proximity & 4 & $3 \%$ \\
\hline 4 & Human Interest & 10 & $7 \%$ \\
\hline 5 & Timeliness & 50 & $34 \%$ \\
\hline 6 & Weater & 2 & $1 \%$ \\
\hline 7 & Development & 13 & $9 \%$ \\
\hline 8 & Crimes & 24 & $16 \%$ \\
\hline 9 & Conflict & 1 & $1 \%$ \\
\hline 10 & Dissaster & 2 & $1 \%$ \\
\hline 11 & Sport & 2 & $1 \%$ \\
\hline & Jumlah & 146 & 100 \\
\hline
\end{tabular}

Tabel diatas dapat diketahui bahwa penyajian berita lokal "Warta 21" di TVRI Bangka Belitung dari dilihat dari nilai beritanya dikategorikan mayoritas berita dengan nilai berita timeliness dan yang paling sedikit kategori yang bernilai berita, weater, conflict, Dissaster dan sport .

Hal ini dengan pertimbangan kebijakan redaksi bahwa liputan yang dilakukan berdasarkan pada mana yang paling banyak dampak yang ditimbulkan atau yang berdampak lebih luas.

Kategori pengukuran berita lokal "Warta 21" yang penulis sajikan dibawah ini adalah berita harian yang meliputi kategori: berdasarkan jenis liputan.

Tabel 5

Berdasarkan Jenis Liputan 


\begin{tabular}{|c|l|c|c|}
\hline No & Jenis Liputan & Frekuensi & Persentase \\
\hline 1 & Liputan Fenomena & 36 & $25 \%$ \\
\hline 2 & Liputan Momentum & 27 & $18 \%$ \\
\hline 3 & Liputan terencana & 58 & $40 \%$ \\
\hline 4 & Liputan lanjutan & 25 & $17 \%$ \\
\hline & & 146 & \\
\hline
\end{tabular}

Tabel diatas dapat diketahui bahwa penyajian berita lokal "Warta 21" di TVRI Bangka Belitung dari dilihat dari jenis liputannya beritanya mayoritas dikategorikan dari liputan terencana dan yang paling sedikit dari liputan lanjutan, hal ini dengan pertimbangan kebijakan redaksi bahwa liputan yang dilakukan berdasarkan pada isu yang sedang berkembang kebanyakan tentang apa.

\section{Simpulan}

Setelah disajikan dan dianalisis, penulis dapat menggambil kesimpulan dari penelitian ini bahwa dari permasalahan bagaimana analisis isi berita lokal dalam acara "Warta 21" di TVRI Bangka Belitung edisi bulan September 2017 dilihat dari berdasarkan materi berita, berdasarkan narasumber, berdasarkan nilai berita, dan berdasarkan jenis liputan yaitu:

1. Penyajian berita lokal "Warta 21 " di TVRI Bangka Belitung dari dilihat dari materi beritanya mayoritas berita sosial kemudian berita kejahatan dan berita yang materi beritanya sedikit adalah Berita Bencana, Transportasi, Budaya, Cuaca, Ilmiah, dan Kecelakaan. Hal ini disebabkan karena materi berita yang diambil oleh reporter di TVRI Bangka Belitung dengan pertimbangan bahwa materinya tergantung dari perkembangan isu-isu pada hari tersebut.

2. Penyajian berita lokal "Warta 21" di TVRI Bangka Belitung dari dilihat dari narasumber dikategorikan mayoritas narasumber dari pemerintah dan yang paling sedikit dari narasumber dari masyarakat. Hal ini disebabkan karena persoalan yang dihadapi oleh masyarakat Bangka Belitung banyak melibatkan aparat pemerintah, dan di Bangka Belitung minim mencari seorang pengamat dari permasalahan yang dihadapi.

3. Penyajian berita lokal "Warta 21" di TVRI Bangka Belitung dari dilihat dari nilai beritanya dikategorikan mayoritas berita dengan nilai berita timeliness dan yang paling sedikit kategori yang bernilai berita Weater, conflict, Dissaster dan sport .

Hal ini dengan pertimbangan kebijakan redaksi bahwa liputan yang dilakukan berdasarkan pada mana yang paling banyak dampak yang ditimbulkan atau yang berdampak lebih luas.

4. Tabel diatas dapat diketahui bahwa penyajian berita lokal "Warta 21" di TVRI Bangka Belitung dari dilihat dari jenis liputannya beritanya mayoritas dikategorikan dari liputan terencana dan yang paling sedikit dari liputan lanjutan. Hal ini dengan pertimbangan kebijakan redaksi bahwa liputan yang dilakukan berdasarkan pada isu yang sedang berkembang kebanyakan tentang apa.

\section{Daftar Pustaka}

Assegaf H. Djaafar. 1991. Jurnalistik Massa Kini. Jakarta: Ghalia Indonesia Badjuri, A. 2010. Jurnalistik Televisi. Yogyakarta:Graha Ilmu.

Junaedi, F. 2013. Jurnalisme Penyiaran dan Reportase Televisi. Jakarta:Kencana Prenada Media Group. 
Eriyanto. 2011. Analisis Isi Program Metodologi Untuk Penelitian Ilmu Komunikasi \& Ilmu-Ilmu Sosial Lainnya. Jakarta: Kencana Prenada Media Group. Martono, N. 2010. Metode Penelitian Kuantitatif. Jakarta:PT Raya Grafindo Persada. Masduki.2001. Jurnalistik Radio. Yogyakarta:Pustaka Populer. Mudda, D. I. 2003. Jurnalistik Televisi, Menjadi Reporter Professional. Bandung: Remaja Rosdakarya.
Narendra. 2008. Metodologi Riset Komunikasi. Panduan untuk Melaksanakan Penelitian Komunikasi. Yogyakarta. Sevilla, Consuelo G. et. al (2007). Research Methods. Rex Printing Company. Quezon City. Wahyudi, JB.1996. Dasar-Dasar Jurnalistik Radio dan Televisi. Jakarta:Pustaka Utama Grafitti. 